\title{
EFFECT OF APPLIED DIFFERENT NITROGEN SOURCES AND SOME BIO-ORGANO-STIMULANTS ON SWEET PEPPER PLANTS GROWN ON A SALINE CALCAREOUS SOIL
}

\author{
Raafat N. Zaki and Habashy R. Nader \\ Soils, Water and Environ. Res. Inst., Agric. Res. Center, Giza, Egypt
}

\section{ABSTRACT:}

A field experiment was carried out on a saline calcareous soil cultivated with sweet pepper plants (Capsicum annuиm L.) under drip irrigation system at a private farm, Nubaria region, El Beheira Governorate, Egypt during two successive seasons 2009 and 2010. The aim target of the current study was identified the effect of soil application for different $\mathrm{N}$-source of (ammonium nitrate, calcium nitrate and ammonium sulfate) as solely treatments or in combination with some bio-organo-stimulants (potassium humate, potassium citrate or yeast) on the plant growth parameters, nutritional status, fruit yield and its quality as expressed by titratable acidity, total soluble solids, total carbohydrates, vitamin $\mathrm{C}$, anthocyanin, total polyphenols, and mineral contents ( $\mathrm{Ca}$ and $\mathrm{K}$ ), fruit nitrate, with a special reference to the associated effects on the soil properties and available nutrient contents. The mineral N, P and $\mathrm{K}$ fertilizers in their different forms were applied as the recommended rates after Ministry of Agriculture, i.e., $100 \mathrm{~kg} \mathrm{~N} f e d^{-1}, 48 \mathrm{~kg} \mathrm{~K}_{2} \mathrm{O} \mathrm{fed}^{-1}$ and $15.5 \mathrm{~kg} \mathrm{P}_{2} \mathrm{O}_{5} \mathrm{fed}^{-1}$, while potassium humate at $0.5 \mathrm{~g} \mathrm{~L}^{-1}$, potassium citrate at $1.0 \mathrm{~g} \mathrm{~L}^{-1}$ and yeast at $2 \mathrm{~g} \mathrm{~L}^{-1}$, which added at the same time of applied nitrogen sources through the drip irrigation system. Taking into consideration K-amount of (K-humate+K-citrate) represents $25 \%$ of the applied recommended K-rate.

The obtained results indicated that there were significantly increases in soil organic matter and available nutrients contents as a result of applied different Nsources and bio-organo-stimulants, with a superiority effect for the combined treatment of (ammonium nitrate+ K-humate). On the other hand, soil $\mathrm{pH}$ and ECe were took place a parallel opposite trend, where their values exhibited significantly decreases, with a superiority effect for the previous combined treatment. It is noteworthy to mention that, it could be categorized the applied treatments according to their superiority effects on the studied soil properties into two ascending orders: $\mathrm{Am}-\mathrm{Ni}>\mathrm{Am}-\mathrm{Su}>\mathrm{Ca}-\mathrm{Ni}$ and $\mathrm{K}-\mathrm{Hu}>\mathrm{K}-\mathrm{Ci}>\mathrm{Ye}$ as solely treatments of $\mathrm{N}$-sources and bio-organo-stimulants, respectively. The second order: $(\mathrm{Am}-\mathrm{Ni}+\mathrm{K}-\mathrm{Hu})>(\mathrm{Am}-\mathrm{Ni}+\mathrm{K}-\mathrm{Ci})>(\mathrm{Am}-\mathrm{Ni}+\mathrm{Ye}),(\mathrm{Am}-\mathrm{Su}+\mathrm{K}-\mathrm{Hu})>(\mathrm{Am}-$ $\mathrm{Su}+\mathrm{K}-\mathrm{Ci})>(\mathrm{Am}-\mathrm{Su}+\mathrm{Ye})$ and $(\mathrm{Ca}-\mathrm{Ni}+\mathrm{K}-\mathrm{Hu})>(\mathrm{Ca}-\mathrm{Ni}+\mathrm{K}-\mathrm{Ci})>(\mathrm{Ca}-\mathrm{Ni}+\mathrm{Ye})$ as the applied combined treatments.

As for plant parameters of sweet pepper, the data showed that the effective role of the applied treatments on leaf number/plant, branch number/plant, plant height, leaves weight/plant and nutritional status as well as fruit yield and its quality parameters behaved a similar parallel trend as was achieved with the studied soil properties. That was true, since the achieved favourable amelioration in soil properties was positively effected on the plant growth parameters, fruit yield and its quality. Moreover, such findings are confirmed by the best effective role of the combined treatment (ammonium nitrate+ K-humate) that was also achieved the greatest values in plant growth parameters as well as fruit yield and quality of sweet pepper.

Fayoum J. Agric. Res. \& Dev., Vol.25, No.1, January, 2011 
Key words: Sweet pepper, N-sources, Bio-organo-stimulants (K-citrate, K-humate and yeast), saline calcareous soil, drip irrigation system.

\section{INTRODUCTION:}

Sweet pepper (Capsicum annuum L.) is one of the most valuable vegetables grown on newly reclaimed land in Egypt. Peppers are an important source of nutrients in the human diet and an excellent source of vitamins $\mathrm{A}$ and $\mathrm{C}$ as well as phenolic compounds that are important antioxidants. Levels of these compounds can vary by genotypes and maturities as well as growing conditions (Guil-Guerreo and Martinez-Guirado, 2006). Growth, yield and nutritional value of vegetable crops are largely affected by the applied fertilizers (Schuphan, 1974). So, it is imperative to grow the crop under the most optimum nutrient conditions thus the producer can get the highest profitable yield and also to obtain fruits rich in the nutritional constituents which are vital for health (McNeal et al., 1995).

Nitrogen is one of the major nutrients that have many important roles in plant development and physiological process. Improved $\mathrm{N}$ management can be achieved by matching $\mathrm{N}$ supply with crop needs, improved timing of fertilizer application, and selecting appropriate $\mathrm{N}$ sources (Hochmuth $\boldsymbol{e t}$ al., 1987). Usually plants are able to take up $\mathrm{N}$ as nitrate $\left(\mathrm{NO}_{3}^{-}\right)$and ammonium $\left(\mathrm{NH}_{4}^{+}\right)$, but some may prefer one source or another depending on plant species. Nitrogen sources may affect plant growth via many processes within the soil plant system and inside the plant (Wiesler, 1997). The most predominant $\mathrm{N}$ forms in commercial fertilizers in Egypt are nitrate $\left(\mathrm{NO}_{3}{ }^{-}\right)$, ammonium $\left(\mathrm{NH}_{4}{ }^{+}\right)$. The response of pepper plants to nitrogen form varies where the nitrate form gave taller plants with bigger girths, which looked greener, had more fruits and gave higher yield than the other $\mathrm{N}$ sources. Since fertilizing $\mathrm{N}$ in nitrate form gave $72-101 \%$ greater yields than ammonium form (Nielsen 1998). Similar results were obtained by Sarro et al. (1995) who found that using $\mathrm{NH}_{4}{ }^{+}-\mathrm{N}$ decreased fruit yield especially when it was applied for longer periods during the growing season. Moreover, Houdusse et al. (2007) mentioned that ammonium and/or nitrate caused a significant decrease in pepper plant growth and the presence of nitrate corrected the negative effects of mixed nitrogen forms containing ammonium and/or nitrate on plant growth. Also the highest plant growth, fruit yield, and largest leaf area in hydroponically grown zucchini squash (Cucurbita pepo $3 \mathrm{~L}$. cv. Green Magic) resulted when $\mathrm{NO}_{3}-\mathrm{N}$ was the sole form of $\mathrm{N}$ than when $\mathrm{NH}_{4}-\mathrm{N}$ was part of the $\mathrm{N}$ treatment (Chance et al., 1999).

On the other hand, Xu et al. (2002) reported that $\mathrm{N}$ form had no significant effect on early fruit yield of sweet pepper (Capsicum annuиm L. cv. Hazera 1195) while, replacing of $\mathrm{NO}_{3}-\mathrm{N}$ by $\mathrm{NH}_{4}-\mathrm{N}$ increased total fruit yield. In many production areas, foliar spray with biostimulant products are becoming more common for the purpose of improving production and quality. These products vary in chemical composition and often contain mixture of organic and inorganic compounds including essential macro- and micronutrients, K-humates, K-citrates and yeast. Potassium humat substances appear to be beneficial in nutrients, preventing their tie up on plant leaves and improving conductivity of nutrients into plant tissue, resulting in more efficient utilization of nutrients (Beames, 1986).

Fayoum J. Agric. Res. \& Dev., Vol.25, No.1, January, 2011 
Potassium humate can be used as organic potash fertilizers. It supplies high levels of soluble potassium in readily available forms. Combined with potassium humat, can be rapidly absorbed and incorporated into plant whether via soil or foliar application methods. Enhancement of plant growth using potassium humate had been reported to be due to increasing nutrients uptake such as $\mathrm{N}, \mathrm{P}, \mathrm{K}, \mathrm{Ca}, \mathrm{Mg}$, $\mathrm{Fe}, \mathrm{Zn}$ and $\mathrm{Cu}$ (David et al.,1994) enhancing photosynthesis, chlorophyll density and plant root respiration which resulted in greater plant growth and yield (Chen and Aviad., 1990). On the other hand, there is several reports indicated the beneficial effect of $\mathrm{K}$ - humat on plant growth and one of the major roles to reduce phytotoxicity and thus increasing yield and quality (Cox and Nelson, 1984).

Ammonia loss is governed by soil factors such as $\mathrm{pH}$, cation exchange capacity, temperature and moisture (Ahmed, et al., 2002). The amount of ammonia- $\mathrm{N}$ loss ranges from 10-60\% of the total $\mathrm{N}$ applied (Baraldi, et al., 1991) with the ever growing concern about the polluting effect of excessive use of nitrogen fertilizers on the environment, improvement of ammonia-N use efficiency in agriculture can not be over emphasized. One of the approaches that could be used to improve $\mathrm{N}$ use efficiency is to mix it with acidic organic materials such as $\mathrm{K}$-humat and $\mathrm{K}$-citrate which have the ability to retain $\mathrm{NH}_{4}{ }^{+}$ions from ammonia-N during hydrolysis and at the same time reducing $\mathrm{pH}$ during hydrolysis. Organic carbon (K- humate, K-citrate and yeast) is known to play an important role in providing plant nutrients as well as interfering in aggregate stability under favorable conditions (Bryan, 1976). K-substances have a good effect in controlling $\mathrm{N}$ loss from $\mathrm{NH}_{4}-\mathrm{N}$ and $\mathrm{NO}_{3}-\mathrm{N}$, even in small quantities, thus this attempt was made to evaluate its effectiveness on pepper. A previous study showed that humic acid has a great effect in reducing $\mathrm{N}$ loss. Whilst, humate could give a direct effect to plant photosynthesis, chlorophyll density and plant root respiration, which simultaneously affect and promote plant growth (Chance, et al., 1999). Yeast is considered as a natural source of cytokinins that stimulates cell division and enlargement as well as the synthesis of protein, nucleic acid and chlorophyll (Ebeed and Abd El-Migeed, 2005). The mixtures supplements of fertilizers can compensate for the constraining effects on nutrient availability and uptake usually presented in the new reclaimed lands (Guertal, 2000).

The main interest in this study was to evaluate the most proper nitrogen sources and some bio-organo-stimulants (potassium humate, potassium citrate and yeast) for a newly reclaimed saline calcareous soil under drip irrigation system, with a special reference to find out whether of these treatments that had a beneficial effect on yields as well as on fruit quality of sweet pepper.

\section{MATERIALS AND METHODS:}

A field experiment was conducted on a saline calcareous soil at a private farm, Nubaria region, El Beheira Governorate, Egypt during two successive seasons of 2009 and 2010. Four weeks-age sweet pepper seedlings (Capsicum annuит L.) were obtained from a local commercial nursery. Healthy seedlings of uniform size were selected and transplanted on Feb. 26, 2009 and Feb. 28, 2010. A split plot design, with three replicates was used. The studied treatments were carried in fixed plots of $3.5 \times 3 \mathrm{~m}\left(10.5 \mathrm{~m}^{2}\right)$ for each one.

Fayoum J. Agric. Res. \& Dev., Vol.25, No.1, January, 2011 
The main treatments were potassium humate $\left(0.5 \mathrm{~g} \mathrm{~L}^{-1}\right)$ or potassium citrate $\left(1.0 \mathrm{~g} \mathrm{~L}^{-1}\right)$ and yeast $\left(2.0 \mathrm{~g} \mathrm{~L}^{-1}\right)$. At the same time, a control was treated with water.

A drip irrigation system was set up to deliver water and nutrients though injection into the irrigation system. The applied fertilizer rate were calculated on the basis of 12000 emitters fed $^{-1}, 30 \mathrm{~cm}$ between both two emitter, $100 \mathrm{~cm}$ between both two lines and discharge of $4 \mathrm{~L} \mathrm{~h}^{-1}$ of each emitter. Each sweet pepper seedling was transplanted just an emitter placed.

Some physical, chemical and fertility properties of the investigated soil are presented in Table (1), which were determined according to the methods described by Piper (1950), Richards (1954) and Jackson (1973). Available N, P and K contents were extracted by $1 \%$ potassium sulphate, $0.5 \mathrm{M}$ sodium bicarbonate and $1 \mathrm{~N}$ ammonium acetate, respectively, and determined according to Jackson (1973). Available micronutrient contents of $\mathrm{Fe}, \mathrm{Mn}, \mathrm{Zn}$ and $\mathrm{Cu}$ were extracted by DTPA (Lindsay and Norvall, 1978) and determined using Atomic Absorption Spectrophtometer.

Table (1): Some physical and chemical properties of the experimental soil.

\begin{tabular}{|c|c|c|c|c|c|c|}
\hline \multicolumn{3}{|c|}{ Soil characteristics } & Value & \multicolumn{2}{|c|}{ Soil characteristics } & Value \\
\hline \multicolumn{4}{|c|}{ Particle size distribution\%: } & \multicolumn{3}{|c|}{ Soluble cations $\left(m\right.$ molc $\left.L^{-1}\right)$} \\
\hline \multicolumn{3}{|c|}{$\begin{array}{l}\text { Sand } \\
\text { Sal }\end{array}$} & 48.23 & \multicolumn{2}{|c|}{$\mathrm{Ca}^{2+}$} & 14.80 \\
\hline \multicolumn{3}{|l|}{ Silt } & 29.12 & \multicolumn{2}{|l|}{$\mathrm{Mg}^{2+}$} & 11.90 \\
\hline \multicolumn{3}{|c|}{ Clay } & 22.65 & \multicolumn{2}{|l|}{$\mathrm{Na}^{+}$} & 26.20 \\
\hline \multicolumn{3}{|c|}{ Textural class } & SCL* & \multicolumn{2}{|l|}{$\mathrm{K}^{+}$} & 0.700 \\
\hline \multicolumn{4}{|c|}{ Soil chemical properties: } & \multicolumn{3}{|c|}{ Soluble anions ( $m$ molc $\left.L^{-1}\right)$} \\
\hline \multirow{4}{*}{\multicolumn{3}{|c|}{$\begin{array}{l}\mathrm{pH}(1: 2.5 \text { soil water suspension }) \\
\mathrm{CaCO}_{3} \% \\
\text { Organic matter } \% \\
\mathrm{ECe}(\mathrm{dS} / \mathrm{m}, \text { soil paste extract })\end{array}$}} & 8.40 & \multicolumn{2}{|c|}{$\mathrm{CO}_{3}{ }^{2-}$} & 0.00 \\
\hline & & & 35.60 & \multicolumn{2}{|l|}{$\mathrm{HCO}_{3}^{-}$} & 2.90 \\
\hline & & & 0.67 & \multicolumn{2}{|l|}{$\mathrm{Cl}^{-}$} & 37.50 \\
\hline & & & 5.32 & \multicolumn{2}{|l|}{$\mathrm{SO}_{4}^{2-}$} & 13.20 \\
\hline \multicolumn{7}{|c|}{ Available macro \& micronutrients $\left(\mathrm{mg} \mathrm{kg}^{-1}\right)$} \\
\hline $\mathrm{N}$ & $\mathrm{P}$ & $\mathrm{K}$ & & \begin{tabular}{|l|l}
$\mathrm{e}$ & $\mathrm{Mn}$ \\
\end{tabular} & $\mathrm{Zn}$ & $\mathrm{Cu}$ \\
\hline 27.1 & 4.94 & 209.9 & & 0.84 & 0.48 & 0.32 \\
\hline
\end{tabular}

Also, based on the recommended fertilizer doses of pepper plants, which received $100 \mathrm{~kg} \mathrm{~N} \mathrm{fed}^{-1}$, the $\mathrm{N}$-different sources were applied through drip irrigation system intervals. $\mathrm{P}$ and $\mathrm{K}$ fertilizers were applied as $15.5 \mathrm{~kg} \mathrm{P}_{2} \mathrm{O}_{5}$ fed $^{-1}$ $36 \mathrm{~kg} \mathrm{~K} \mathrm{~K}_{2} \mathrm{O} \mathrm{fed}^{-1}$, and incorporated to the soil before planting. Taking into consideration $\mathrm{K}$-amount of (K-humate+K-citrate) represents $25 \%$ of the applied recommended K-rate. Irrigation was regularly monitored according to weather conditions to keep the moisture content at the optional level. At the same time, control treatment was irrigated with water to exclude the effect of application.

Four whole plant samples per plot were selected at 75 days after transplanting for determining the vegetative growth (i.e. plant height, number of branches, plant fresh and dry weights). When the fruits reached their maturity, plant yield of ripe fruits were harvested, were fruit harvested four times during the season. Yield was determined by counting and weighting all mature fruits on each plant. The combined yield of the four harvests was considered as total yield.

Fayoum J. Agric. Res. \& Dev., Vol.25, No.1, January, 2011 
Random samples of 20 fruits in each treatment were selected to measure the quality of the fruit, which are the properties related to color, odor and taste as expressed by measuring total soluble solids (TSS) and titratable acidity (AOAC, 1990). About ten grams of fresh fruit sample was blended and the juice was used to measure TSS using standard handheld refracto meter. Titratable acidity in fruit juice was measured by volumetric titration with standardized $0.1 \mathrm{~N}$ sodium hydroxide, using phenolphthalein as an internal indicator and expressed as \% citric acid (AOAC, 1990). For determining total carbohydrates, $0.5 \mathrm{~g}$ of dried fruits was placed in a test tube, and $10 \mathrm{ml}$ of sulfuric acid $(1 \mathrm{~N})$ was added, and then tube was sealed and placed overnight in an oven at $100^{\circ} \mathrm{C}$. After that the solution was then filtered into a measuring flask. The total sugars were determined colorimetrically according to the method of Smith et al. (1956).

Vitamin $\mathrm{C}$ was determined by using the 2, 6 dichlorophenol-indophenol dyes according to method described by Nielsen (1998), where $1 \mathrm{~g}$ of fresh fruit tissue was weighed and grounded using mortar and pestle with addition of $2 \mathrm{ml}$ of metaphosphoric acetic acid. The mixture was filtered and the extract was made up to $10 \mathrm{ml}$ with the metaphosphoric-acetic acid mixture. Five $\mathrm{ml}$ of the metaphosphoric-acetic acid solution was pipetted followed by $2 \mathrm{ml}$ of the samples extract. The samples were titrated separately with the indophenol dye solution until a light rose pink persisted for $5 \mathrm{sec}$. The amount of dye used in the titration was determined and used in the calculation of vitamin $\mathrm{C}$ content $(\mathrm{mg} / 100 \mathrm{~g} \mathrm{FW})$. Anthocyanins were determined in air dried pepper fruits as the method described

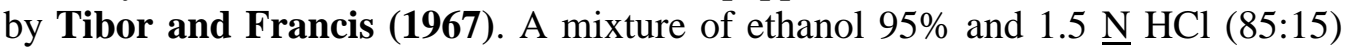
was prepared and its $\mathrm{pH}$ was adjusted to 1 . A known mass was macerated with 50 $\mathrm{ml}$ extracting solvent and stored at $4^{\circ} \mathrm{C}$. The extract was completed to a known volume with extracting solvent. The color of the extract was measured at the absorption maximum (520nm) using Spectrophotometer.

Determining of total polyphenols, where $0.5 \mathrm{~g}$ of dried fruits was blended with $40 \mathrm{ml}$ of $70 \%$ aqueous acetone then boiled to extract the total polyphenols and was left to cool. The mixture was then filtered and the residue was mixed with another $20 \mathrm{ml}$ of $70 \%$ aqueous acetone and the extraction process was repeated twice. Ten drops of concentrated hydrochloric acid were added to $1 \mathrm{ml}$ of the extract, and then heated rapidly to boiling in a water bath for about 10 minutes. After cooling, $1 \mathrm{ml}$ of the Folin-Ciocalteu reagent and $1.5 \mathrm{ml}$ of sodium carbonate solution $(14 \%)$ were added. The mixture was diluted to $10 \mathrm{ml}$ with distilled water then thoroughly mixed. The reaction mixture was heated in boiling water for 5 minutes, and then cooled. The developing color was measured at $520 \mathrm{~nm}$ using spectrophotometer as described by Wettasinghe and Shahidi (1999).

Soil samples were collected, air-dried, ground and passed through a $2 \mathrm{~mm}$ sieve and assessed for particle size distribution, water holding capacity, and soil reaction. The electrical conductivity, water soluble cations and anions were determined in the extract of the saturated soil paste the available $\mathrm{N}, \mathrm{P}$ and $\mathrm{K}$ nutrients were determined by Black et al. (1982).

All data were averaged for the successive two seasons and subjected to the analysis of variance (ANOVA), using least significant difference (L.S.D) at $P=$ 0.05, according to Gomez and Gomez (1984).

Fayoum J. Agric. Res. \& Dev., Vol.25, No.1, January, 2011 


\section{RESULTS AND DISCUSSION:}

The dramatic increase in using fertilizers and higher production costs in the recent years requires more attention from producers to reduce pollution and production cost. This reduction can be obtained by selecting the proper form of fertilizers that is suitable for the soil type and plant species as well as using a beneficial biostimulants to obtain a real increase in crop yield and quality as well as high economic return.

\section{Soil characteristics and available nutrients:}

\section{a) Some soil properties:}

The effects of applied different $\mathrm{N}$-sources and bio-organo-stimulants treatments on some soil properties at the maximum vegetative growth stage are presented in Table (2). The results showed that the soil organic matter was significantly increased as a result of applied different $\mathrm{N}$-sources and bio-organostimulants, being an ascending order of Am-Nit $>\mathrm{Am}-\mathrm{Su}>\mathrm{Ca}-\mathrm{Ni}$ vs. $\mathrm{K}-\mathrm{Hu}>\mathrm{K}-\mathrm{Ci}$ $>\mathrm{Ye}$ as solely treatments. The relative increase percentages in soil organic matter at the applied treatments $\mathrm{N}$-sources plus $\mathrm{K}-\mathrm{Hu}, \mathrm{K}-\mathrm{Ci}$ and Ye were 13.79, 11.76 and $7.31 \%$ as a mean value, respectively. The corresponding values for bio-stimulants plus $\mathrm{Am}-\mathrm{Ni}, \mathrm{Am}-\mathrm{Su}$ and $\mathrm{Ca}-\mathrm{Ni}$ were 17.72, 16.88 and $15.79 \%$, respectively. The main effects of applied K-humat, K-citrate and yeast treatments were imposed, with a significant trend at $P=0.05$. The interactions revealed that the variations in soil organic matter for any applied $\mathrm{N}$-sources were limited among $\mathrm{K}$-humate, $\mathrm{K}$ citrate and yeast, imposing significant differences. These significant increases were among the combined treatment of $(\mathrm{Am}-\mathrm{Ni}+\mathrm{K}-\mathrm{Hu})$, with an increase percentage of $47.07 \%$ over the control treatment.

Table (2): Some soil characteristic at a maximum vegetative growth stage as affected by the applied $\mathrm{N}$-sources and bio-organo-stimulants.

\begin{tabular}{|c|c|c|c|c|c|c|}
\hline \multirow{2}{*}{ Treatments $(\mathbf{T})$} & \multicolumn{4}{|c|}{ Biostimulants (Bi) } & \multirow{2}{*}{ Mean } & \multirow{2}{*}{$\begin{array}{l}\text { L.S.D. } \\
\text { at } 5 \%\end{array}$} \\
\hline & $\mathbf{0}$ & K-Hu & K-Cit & Yeast & & \\
\hline \multicolumn{7}{|c|}{ Organic matter \% } \\
\hline Control & 0.68 & 0.87 & 0.85 & 0.82 & 0.81 & \multirow{5}{*}{$\begin{array}{c}\mathrm{T}=0.03 \\
\mathrm{Bi}=0.03 \\
\mathrm{~T} \times \mathrm{Bi}=0.05\end{array}$} \\
\hline Ammonium nitrate & 0.79 & 1.00 & 0.98 & 0.94 & 0.93 & \\
\hline Calcium nitrate & 0.76 & 0.96 & 0.93 & 0.88 & 0.88 & \\
\hline Ammonium sulfate & 0.76 & 0.98 & 0.96 & 0.90 & 0.90 & \\
\hline Mean & 0.74 & 0.99 & 0.95 & 0.88 & & \\
\hline \multicolumn{7}{|c|}{ Soil pH } \\
\hline Control & 8.35 & 8.00 & 8.09 & 8.12 & 8.05 & \multirow{5}{*}{$\begin{array}{c}\mathrm{T}=0.08 \\
\mathrm{Bi}=0.10 \\
\mathrm{~T} \times \mathrm{Bi}=0.18\end{array}$} \\
\hline Ammonium nitrate & 7.76 & 7.31 & 7.33 & 7.63 & 7.54 & \\
\hline Calcium nitrate & 7.80 & 7.62 & 7.82 & 7.92 & 7.79 & \\
\hline Ammonium sulfate & 7.77 & 7.81 & 7.90 & 8.01 & 7.76 & \\
\hline Mean & 7.92 & 7.66 & 7.82 & 7.91 & & \\
\hline \multicolumn{7}{|c|}{$\mathrm{EC}, \mathrm{dSm}^{-1}$} \\
\hline Control & 5.35 & 5.37 & 5.35 & 5.35 & 5.36 & \multirow{5}{*}{$\begin{array}{c}\mathrm{T}=0.30 \\
\mathrm{Bi}=0.40 \\
\mathrm{~T} \times \mathrm{Bi}=0.50\end{array}$} \\
\hline Ammonium nitrate & 5.30 & 2.65 & 2.97 & 2.88 & 3.45 & \\
\hline Calcium nitrate & 4.99 & 3.27 & 3.87 & 3.28 & 3.85 & \\
\hline Ammonium sulfate & 5.22 & 3.33 & 4.00 & 3.31 & 3.97 & \\
\hline Mean & 5.22 & 3.66 & 3.92 & 3.71 & & \\
\hline
\end{tabular}

Fayoum J. Agric. Res. \& Dev., Vol.25, No.1, January, 2011 
The data documented proved that soil moisture and nutrient retention were relatively improved due to the applied bio-organo-stimulants, which enhancing markedly increased organic substances. It could be emphasized lay such bioorgano-stimulants to ameliorate soil aggregation that acts well for improving the soil moisture characteristics. On the assessment of the proposed treatment variables on soil $\mathrm{pH}$, the results presented in Table (2) indicated that the detected soil $\mathrm{pH}$ was significantly affected by the main effect of bio-organo-stimulants treatments. The changes in soil $\mathrm{pH}$ between $\mathrm{K}-\mathrm{Hu}, \mathrm{K}-\mathrm{Ci}$ and yeast treatments and the control were actually limited by $0.23-0.35$ units. On the contrary, the effect of soil applications imposed remarkable variations on soil $\mathrm{pH}$ among the different $\mathrm{N}$-sources. The LSD comparison proved that the changes in soil $\mathrm{pH}$ between the respective $\mathrm{N}$-sources and the control ranged from 0.23 to 1.04 units. As expected, the lowest $\mathrm{pH}$ was recorded from $\mathrm{NH}_{4}$ treatment. Ammonium nitrate is an important $\mathrm{N}$ fertilizer in agriculture. However, in this study it failed to improve dry matter production as compared to the other treatments although the concentration of $\mathrm{NH}_{4}{ }^{+}$under bioorgano-stimulants treatments (K-humate, $\mathrm{K}$-citrate and yeast), such treatment was the highest in terms of $\mathrm{NH}_{4}{ }^{+}$accumulation, $\mathrm{K}-\mathrm{Hu}$ was more effective as compared to the other treatments.

The low $\mathrm{pH}$ of the soil treated with organic based $\mathrm{N}$ fertilizers does not necessarily suggest that those treatments did not markedly decrease the $\mathrm{pH}$ of the soil. Their effect could be temporary as reported by Ahmed $\boldsymbol{e t}$ al. (2006), where a short term effect of nitrogen sources mixed with acidic materials temporarily reduced soil $\mathrm{pH}$. The tendency of $\mathrm{HA}$ to react with $\mathrm{NH}_{4}$, released by ammonium, was high in the formulated fertilizers consisting $\mathrm{HA}$. The presence of high $\mathrm{NH}_{4}{ }^{+}$ due to continues hydrolysis of ammonium and overload of $\mathrm{NH}_{4}{ }^{+}$could enhance fixation processes (Ahmed $\boldsymbol{e}$ al., 2008). The acidic nature of $\left(\mathrm{NH}_{4}\right)_{2} \mathrm{SO}_{4}$ reduced its effect on dry matter production. This acidity without liming may cause poor plant growth and development. As for ammonium sulfate, in the form of sulfate $\left(\mathrm{SO}_{4}{ }^{2-}\right)$ reduces soil $\mathrm{pH}$ and affects $\mathrm{NH}_{3}{ }^{+}$volatilization functional groups present in humic molecules together with its characteristics produced a lot of effects on $\mathrm{NH}_{4}{ }^{+}$ recovery. Less oxygen functional groups present in HA reduced soil exchangeable $\mathrm{NH}_{4}{ }^{+}$(Guil-Guerrero and. Martinez-Guirado (2006). However, may have enabled the humic molecules to retain more $\mathrm{NH}_{4}{ }^{+}$at this low $\mathrm{pH}$. Hence, the low cation exchange capacity (total acidity) of $\mathrm{K}-\mathrm{Hu}$ could be one of the reasons for inefficiency of HA. According to Tan (2005), the total acidity of HA varies from 7.4-8.1 meq g ${ }^{-1}$, while that of citric acid, ranges between 7.5 and $8.2 \mathrm{meq} \mathrm{g}^{-1}$. The interaction study of the variable treatments did not appear any significant trend at $P$ $=0.05$.

The relative drop in $\mathrm{EC}_{\mathrm{S}}$ values among the variable biostimulants could be particularly inferred efficiency of K-HA in enhancing all removal from the studied soil due creating the conductive pores between the soil stable aggregates. The low amount of K-HA used in fertilizer formulation could be a significant factor. Since, K-humat substances are believed to contain a very small amount of permanent charges which are responsible for CEC development with $10 \%$ estimation from its total negative charges (Tan et al., 1992.), its contribution to cations retention would be subjective and relying on its quantity used.

Fayoum J. Agric. Res. \& Dev., Vol.25, No.1, January, 2011 


\section{b. Status of soil nutrient availability at the Harvest stage:}

The results outlined in Table (3a) showed the positive effects of the applied $\mathrm{K}$-humate on available contents of $\mathrm{N}, \mathrm{P}$ and $\mathrm{K}$ exhibiting an ascending order of $\mathrm{K}$ $\mathrm{Hu}>\mathrm{K}-\mathrm{Ci}>\mathrm{Ye}>$ control.

Table (3a): Soil macro and micronutrients content at the harvest as affected by Nsources and bio-organo-stimulants applications.

\begin{tabular}{|c|c|c|c|c|c|c|}
\hline \multirow{2}{*}{ Treatments $(\mathbf{T})$} & \multicolumn{4}{|c|}{ Biostimulants (Bi) } & \multirow{2}{*}{ Mean } & \multirow{2}{*}{$\begin{array}{l}\text { L.S.D. } \\
\text { at } 5 \%\end{array}$} \\
\hline & $\mathbf{0}$ & K-Hu & K-Cit & Yeast & & \\
\hline \multicolumn{7}{|c|}{$\mathbf{N}, \mathbf{m g ~ k g}^{-1}$} \\
\hline Control & 2.78 & 29.8 & 30.5 & 30.1 & 29.7 & \multirow{5}{*}{$\begin{array}{c}\mathrm{T}=1.10 \\
\mathrm{Bi}=0.20 \\
\mathrm{~T} \times \mathrm{Bi}=2.10\end{array}$} \\
\hline Ammonium nitrate & 2.98 & 42.7 & 41.2 & 39.5 & 38.3 & \\
\hline Calcium nitrate & 28.5 & 39.5 & 38.1 & 35.1 & 35.3 & \\
\hline Ammonium sulfate & 28.1 & 40.2 & 39.7 & 37.9 & 36.5 & \\
\hline Mean & 28.6 & 38.1 & 37.4 & 35.7 & & \\
\hline \multicolumn{7}{|c|}{$\mathbf{P}, \mathrm{mg} \mathrm{kg}^{-1}$} \\
\hline Control & 5.0 & 6.4 & 6.0 & 5.8 & 5.80 & \multirow{5}{*}{$\begin{array}{c}\mathrm{T}=0.27 \\
\mathrm{Bi}=0.32 \\
\mathrm{~T} \times \mathrm{Bi}=2.20\end{array}$} \\
\hline Ammonium nitrate & 5.7 & 7.9 & 7.8 & 7.0 & 7.10 & \\
\hline Calcium nitrate & 5.3 & 6.9 & 6.5 & 6.4 & 6.28 & \\
\hline Ammonium sulfate & 5.55 & 7.1 & 7.3 & 7.0 & 6.73 & \\
\hline Mean & 5.38 & 7.07 & 6.90 & 6.55 & & \\
\hline \multicolumn{7}{|c|}{$\mathrm{K}, \mathrm{mg} \mathrm{kg}^{-1}$} \\
\hline Control & 221 & 222 & 220 & 218 & 220.5 & \multirow{5}{*}{$\begin{array}{c}\mathrm{T}=3.90 \\
\mathrm{Bi}=4.10 \\
\mathrm{~T} \times \mathrm{Bi}=6.00\end{array}$} \\
\hline Ammonium nitrate & 217 & 248 & 240 & 219 & 234.0 & \\
\hline Calcium nitrate & 215 & 231 & 230 & 231 & 226.5 & \\
\hline Ammonium sulfate & 220 & 240 & 239 & 230 & 231.7 & \\
\hline Mean & 218.3 & 235.3 & 232.3 & 228.0 & & \\
\hline \multicolumn{7}{|c|}{$\mathrm{Fe}, \mathrm{mg} \mathrm{kg}^{-1}$} \\
\hline Control & 4.30 & 4.90 & 4.70 & 4.80 & 4.67 & \multirow{5}{*}{$\begin{array}{c}\mathrm{T}=0.31 \\
\mathrm{Bi}=0.20 \\
\mathrm{~T} \times \mathrm{Bi}=0.50\end{array}$} \\
\hline Ammonium nitrate & 4.70 & 6.40 & 6.00 & 5.90 & 5.75 & \\
\hline Calcium nitrate & 4.60 & 5.20 & 5.70 & 5.00 & 5.13 & \\
\hline Ammonium sulfate & 4.40 & 6.10 & 5.90 & 5.80 & 5.55 & \\
\hline Mean & 4.50 & 5.65 & 5.56 & 5.37 & & \\
\hline \multicolumn{7}{|c|}{$\mathrm{Mn}, \mathrm{mg} \mathrm{kg}^{-1}$} \\
\hline Control & 0.86 & 0.91 & 0.89 & 0.87 & 0.88 & \multirow{5}{*}{$\begin{array}{c}\mathrm{T}=0.1 \\
\mathrm{Bi}=0.03 \\
\mathrm{~T} \times \mathrm{Bi}=0.18\end{array}$} \\
\hline Ammonium nitrate & 0.90 & 1.45 & 1.43 & 1.40 & 1.29 & \\
\hline Calcium nitrate & 0.87 & 1.00 & 1.00 & 0.95 & 0.96 & \\
\hline Ammonium sulfate & 0.87 & 1.40 & 1.33 & 1.21 & 1.20 & \\
\hline Mean & 0.88 & 1.19 & 1.16 & 1.11 & & \\
\hline \multicolumn{7}{|c|}{$\mathrm{Zn}, \mathrm{mg} \mathrm{kg}^{-1}$} \\
\hline Control & 0.49 & 0.56 & 0.54 & 0.52 & 0.53 & \multirow{5}{*}{$\begin{array}{c}\mathrm{T}=0.24 \\
\mathrm{Bi}=0.02 \\
\mathrm{~T} \times \mathrm{Bi}=0.11\end{array}$} \\
\hline Ammonium nitrate & 0.54 & 1.36 & 1.31 & 1.29 & 1.13 & \\
\hline Calcium nitrate & 0.50 & 1.12 & 1.09 & 1.00 & 0.93 & \\
\hline Ammonium sulfate & 0.52 & 1.29 & 1.32 & 1.21 & 1.09 & \\
\hline Mean & 0.51 & 1.08 & 1.06 & 1.01 & & \\
\hline \multicolumn{7}{|c|}{$\mathrm{Cu}, \mathrm{mg} \mathrm{kg}^{-1}$} \\
\hline Control & 0.34 & 0.39 & 0.35 & 0.37 & 0.36 & \multirow{5}{*}{$\begin{array}{c}\mathrm{T}=0.05 \\
\mathrm{Bi}=0.04 \\
\mathrm{~T} \times \mathrm{Bi}=0.05\end{array}$} \\
\hline Ammonium nitrate & 0.39 & 1.25 & 1.15 & 1.12 & 0.98 & \\
\hline Calcium nitrate & 0.35 & 1.09 & 1.00 & 0.95 & 0.85 & \\
\hline Ammonium sulfate & 0.37 & 1.20 & 1.12 & 1.00 & 0.91 & \\
\hline Mean & 0.36 & 0.98 & 0.91 & 0.86 & & \\
\hline
\end{tabular}

$\mathrm{K}-\mathrm{Hu}=\mathrm{K}-\mathrm{Humate}, \mathrm{K}-\mathrm{Cit}=\mathrm{K}-\mathrm{Citrate}$

Fayoum J. Agric. Res. \& Dev., Vol.25, No.1, January, 2011 
Table (3b): Critical limits of micronutrients after Lindsay and Norvell (1978).

\begin{tabular}{|c|c|c|c|c|}
\hline Critical limits & Fe & Mn & Zn & Cu \\
\hline Low & $<4.0$ & $<2.0$ & $<1.0$ & $>1.0$ \\
\hline Medium & $4.0-6.0$ & $2.0-5.0$ & $0.5-1.0$ & $1.0-1.5$ \\
\hline High & $>6.0$ & $>.5 .0$ & $>1.0$ & $1.9-7.8$ \\
\hline
\end{tabular}

It was noticed that soil treated with $\mathrm{K}-\mathrm{Hu}$ stimulated the leaf $\mathrm{N}, \mathrm{P}, \mathrm{K}$ contents effectively, being the highest when ammonium nitrate was included. The corresponding $\mathrm{N}, \mathrm{P}$ and $\mathrm{K}$ values were $31.6,7.4$ and $225 \mathrm{mg} \mathrm{kg}^{-1}$ for $\mathrm{K}-\mathrm{Hu}$ vs 30.3 , 6.4 and $223 \mathrm{mg} \mathrm{kg}^{-1}$ for $\mathrm{K}-\mathrm{Ci}$, respectively. This could be explained to the stimulatory effect of $\mathrm{K}-\mathrm{Hu}$ on the inoculated $\mathrm{N}$-sources that acted well for releasing more available nutrients from organic substrate (Amin et al 2008).

Regarding the effect of N-sources and bio-organo-stimulants applications used, it was observed that the soil N, P and K contents followed an ascending order of Am-Ni > Am-Su > Ca-Ni. > control. Such variations could be ascribed to the differential reaction of $\mathrm{N}$-sources combined with bio-organo-stimulants on protecting the plant membranes and proteins (Amin et al., 2008). These results are agreement with those reported by Antoun and Besada (1990) who showed that soil N, P and K increased with the application of different organic source. As for organic materials in the soil decay, macromolecules of a mixed aliphatic and aromatic nature are formed. The humic substances in the soil have multiple effects (Amin et al. 2008), where indirect effects involve improvements of soil properties such as aggregation, aeration, permeability, water holding capacity, micronutrient transport and availability (Arfan et al., 2007). Meanwhile, the direct effects are those, which require uptake of humic substances into the plant tissue resulting in various biochemical effects (Amin et al., 2008).

The magnitude of available micronutrients in the studied soil as affected by the applied treatments are shown in Table (3a). The obtained data showed that the studied $\mathrm{Fe}, \mathrm{Mn}, \mathrm{Zn}$ and $\mathrm{Cu}$ lay within the low-medium range according to the critical levels of micronutrients, Table (3b), undertaken by Lindsay and Norvell (1978) for sweet pepper at all applied treatments of N-sources and biostimulants applications under drip irrigation system. In general, this is true since these soils are not only poor in the nutrients bearing minerals, but also in organic and inorganic colloids, which are considered a storehouse for the essential plant nutrients.

\section{Growth and yield performances:}

a. Vegetative growth:

With particular reference to the control, the results reported in Table (4) revealed that the main effects of soil bio-organo-stimulants applications in posed significant trend on the all measured growth criteria at $P=0.05$. Data showed clearly that $\mathrm{N}$-sources and biostimulant application interacted significantly and had a positive effect on all the vegetative growth parameters. It was clear that the greatest values for plant height, number of branches/plant, plant fresh and dry weight in the average of two studied season were obtained by applying ammonium nitrate combined with K-humate as biostimulant.

Fayoum J. Agric. Res. \& Dev., Vol.25, No.1, January, 2011 
On the other hand, ammonium sulfate followed by calcium nitrate treatments with biostimulant application achieved the next favourable values for all these vegetative growth parameters. Regarding biostimulant application, potassium humate was more effective than potassium citrate and yeast in increasing all the studied vegetative growth parameters and both of them showed a significant increase over the control. In respect to, plant height there was insignificant difference between potassium citrate and humate but both biostimulants were significantly higher than control. Several researches found that applying nitrogen fertilizer in the form of ammonium nitrate gave the most vigorous vegetative growth of potato plants (Baker et al., 1980). The enhancement of plant growth due to fertilizing with ammonium nitrate may be attributed to the presence of $\mathrm{N}$ forms, nitrate $\left(\mathrm{NO}_{3}{ }^{-}\right)$and ammonium $\left(\mathrm{NH}_{4}{ }^{+}\right)$that is documented to be superior over sole $\mathrm{NO}_{3}{ }^{-}-\mathrm{N}$ or $\mathrm{NH}_{4}{ }^{+}-\mathrm{N}$ sources (Marchner, 1995).

Table (4): Vegetative growth parameters and fruit yield of sweet pepper as affected by different $\mathrm{N}$-sources and bio-organo-stimulants.

\begin{tabular}{|c|c|c|c|c|c|c|}
\hline \multirow{2}{*}{ Treatments $(\mathbf{T})$} & \multicolumn{4}{|c|}{ Biostimulants (Bi) } & \multirow{2}{*}{ Mean } & \multirow{2}{*}{$\begin{array}{l}\text { L.S.D. } \\
\text { at } 5 \%\end{array}$} \\
\hline & $\mathbf{0}$ & K-Hu & K-Cit & Yeast & & \\
\hline \multicolumn{7}{|c|}{ Plant height $(\mathrm{cm})$} \\
\hline Control & 31.6 & 36.8 & 34.9 & 33.0 & 34.1 & \multirow{5}{*}{$\begin{array}{c}\mathrm{T}=2.70 \\
\mathrm{Bi}=1.20 \\
\mathrm{~T} \times \mathrm{Bi}=1.70\end{array}$} \\
\hline Ammonium nitrate & 37.0 & 53.5 & 50.1 & 42.7 & 45.8 & \\
\hline Calcium nitrate & 32.2 & 50.9 & 48.6 & 39.1 & 42.7 & \\
\hline Ammonium sulfate & 35.8 & 52.8 & 49.1 & 40.5 & 44.6 & \\
\hline Mean & 34.2 & 48.5 & 46.1 & 38.4 & & \\
\hline \multicolumn{7}{|c|}{ Plant fresh weight $(\mathrm{g})$} \\
\hline Control & 79.8 & 100.0 & 90.5 & 87.5 & 108.9 & \multirow{5}{*}{$\begin{array}{c}\mathrm{T}=0.40 \\
\mathrm{Bi}=0.80 \\
\mathrm{~T} \times \mathrm{Bi}=0.50\end{array}$} \\
\hline Ammonium nitrate & 90.5 & 150.9 & 144.7 & 135.2 & 130.3 & \\
\hline Calcium nitrate & 85.7 & 141.7 & 137.8 & 136.1 & 125.3 & \\
\hline Ammonium sulfate & 87.1 & 147.2 & 142.7 & 137.1 & 128.5 & \\
\hline Mean & 85.8 & 136.1 & 127.8 & 123.9 & & \\
\hline \multicolumn{7}{|c|}{ Plant dry weight (g) } \\
\hline Control & 18.8 & 21.7 & 20.5 & 17.7 & 19.7 & \multirow{5}{*}{$\begin{array}{c}\mathrm{T}=1.20 \\
\mathrm{Bi}=0.40 \\
\mathrm{~T} \times \mathrm{Bi}=1.60\end{array}$} \\
\hline Ammonium nitrate & 25.7 & 36.9 & 35.0 & 33.7 & 32.8 & \\
\hline Calcium nitrate & 20.9 & 30.7 & 29.7 & 26.9 & 27.1 & \\
\hline Ammonium sulfate & 22.3 & 33.9 & 34.1 & 31.2 & 30.4 & \\
\hline Mean & 21.9 & 30.9 & 29.7 .1 & 27.4 & & \\
\hline \multicolumn{7}{|c|}{ Total fruit yield (ton fed ${ }^{-1}$ ) } \\
\hline Control & 2.00 & 2.92 & 2.85 & 2.70 & 2.62 & \multirow{5}{*}{$\begin{array}{c}\mathrm{T}=1.60 \\
\mathrm{Bi}=0.90 \\
\mathrm{~T} \times \mathrm{Bi}=1.00\end{array}$} \\
\hline Ammonium nitrate & 3.71 & 6.97 & 5.55 & 4.90 & 5.28 & \\
\hline Calcium nitrate & 2.90 & 3.71 & 3.31 & 3.01 & 3.03 & \\
\hline Ammonium sulfate & 2.89 & 5.83 & 4.93 & 3.52 & 4.29 & \\
\hline Mean & 2.88 & 4.88 & 4.17 & 3.45 & & \\
\hline
\end{tabular}

Moreover, the enhancement of plant growth using potassium humate had been reported to be due to the increase in nutrients uptake or enhancement of photosynthesis, chlorophyll density and plant root respiration which resulted in greater plant growth (Chen and Aviad, 1990). Regarding the yield parameters, it was clear that there was a positive interaction between the two studied factors, i.e., $\mathrm{N}$ forms and biostimulation in increasing all yield components of pepper plants.

Fayoum J. Agric. Res. \& Dev., Vol.25, No.1, January, 2011 
Also, ammonium nitrate combined with potassium humate was the best treatment for increasing the total yield, followed by ammonium sulfate with potassium humate. On the other hand, plants received ammonium nitrate without biostimulant application had the highest early yield followed by calcium nitrate combined with potassium humate.

Moreover, data presented showed that biostimulation either with potassium humate or citrate had a significant effect on total yield. This is might be due to the vegetative growth stimulation by soil application using drip irrigation system of potassium humate or citrate which resulted in a positive delay in flowering and fruiting stages. Similar results were obtained by Ghoname et al., (2009) who mentioned that there was an increase in tomato fruit yield with application of humic acid. The increase in the dry weights of pepper plants might be attributed to an increase in leaf area as well as number of branches, as a result of increasing photosynthetic activity and improvement in plant growth of pepper plants. These results are agreement with those reported by Amin, et al. (2008) who found that a progressive increase in each of plant height, number of spikes, leaf area, and dry

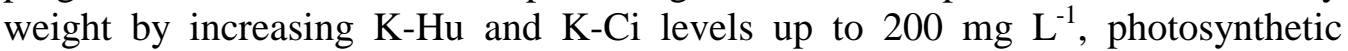
pigments in the leaves. In this connection, Ghoname et al. (2009) found that Nfrom plus $\mathrm{K}-\mathrm{Hu}$ and $\mathrm{K}-\mathrm{Ci}$ application led to increase significantly the dry weights of plants.

The treatment with yeast significantly increased vegetative growth and yield of plants. The positive effects of yeast application were referred to its contents of proteins, amino acids, vitamins and hormones as well as some micro nutrients. All these compounds work as a readily available growth supplements to plants which eventually improve plant growth and production.

\section{b. Plant growth characteristics:}

Leaf number per plant as well as leaves fresh and dry weights followed a similar trend as mentioned above (Table 5) where combining ammonium nitrate source and potassium humate soil application gave the greatest significant values of these parameters. Generally ammonium nitrate was the best $\mathrm{N}$ form followed by ammonium sulfate and calcium nitrate, while potassium humate was superior to potassium citrate and both were significantly higher than control. Similar results were obtained by Soltani et al. (2007) who mentioned that increasing $\mathrm{NH}_{4} \mathrm{~N}$ in nutrient solution caused reduction in cucumber fruit dry matter. The simulative effect of potassium humate in enhancing fruit characteristics may be attributed to that some plant hormone-like substances seem to be present in the humic substances, thus exerting a possible stimulating effect on leaves growth (Pizzeghello, 2002). Generally, all applied materials improved plant vegetative growth such as number of leaves and branches which must have been reflected on total plant leaf area. This means higher light interception and more assimilate production which appeared in the form of high fresh and dry weights of the plants.

c. Leaf nutrient contents:

The data in Table (6) showed that application of potassium humate significantly increased the nutrient contents in pepper leaves, i.e, nitrogen, phosphorus and potassium relative to the control treatment.

Fayoum J. Agric. Res. \& Dev., Vol.25, No.1, January, 2011 
Table (5): Some plant parameters as affected by different $\mathrm{N}$-sources and biostimulants applications.

\begin{tabular}{|c|c|c|c|c|c|c|}
\hline \multirow{2}{*}{ Treatments $(\mathbf{T})$} & \multicolumn{4}{|c|}{ Biostimulants (Bi) } & \multirow{2}{*}{ Mean } & \multirow{2}{*}{$\begin{array}{l}\text { L.S.D. } \\
\text { at } 5 \%\end{array}$} \\
\hline & $\mathbf{0}$ & K-Hu & K-Cit & Yeast & & \\
\hline \multicolumn{7}{|c|}{ Leaf number plant $^{-1}$} \\
\hline Control & 149 & 176 & 156 & 150 & 158 & \multirow{5}{*}{$\begin{array}{c}\mathrm{T}=2.00 \\
\mathrm{Bi}=5.00 \\
\mathrm{~T} \times \mathrm{Bi}=18.0\end{array}$} \\
\hline Ammonium nitrate & 155 & 231 & 200 & 184 & 193 & \\
\hline Calcium nitrate & 142 & 188 & 179 & 167 & 169 & \\
\hline Ammonium sulfate & 150 & 200 & 189 & 178 & 179 & \\
\hline Mean & 149 & 197 & 181 & 169 & & \\
\hline \multicolumn{7}{|c|}{ Number of branches plant ${ }^{-1}$} \\
\hline Control & 8 & 12 & 10 & 11 & 10 & \multirow{5}{*}{$\begin{array}{c}\mathrm{T}=2.00 \\
\mathrm{Bi}=1.00 \\
\mathrm{~T} \times \mathrm{Bi}=2.00\end{array}$} \\
\hline Ammonium nitrate & 13 & 19 & 17 & 14 & 16 & \\
\hline Calcium nitrate & 9 & 15 & 12 & 10 & 12 & \\
\hline Ammonium sulfate & 10 & 17 & 15 & 12 & 14 & \\
\hline Mean & 10 & 16 & 14 & 12 & & \\
\hline \multicolumn{7}{|c|}{ Leave fresh weight $\left(\mathrm{g} \mathrm{plant}^{-1}\right)$} \\
\hline Control & 23.94 & 24.97 & 27.21 & 25.01 & 25.28 & \multirow{5}{*}{$\begin{array}{c}\mathrm{T}=1.40 \\
\mathrm{Bi}=2.21 \\
\mathrm{~T} \times \mathrm{Bi}=3.11\end{array}$} \\
\hline Ammonium nitrate & 24.50 & 37.81 & 35.77 & 27.80 & 31.47 & \\
\hline Calcium nitrate & 22.70 & 31.71 & 28.70 & 21.97 & 26.27 & \\
\hline Ammonium sulfate & 23.43 & 34.05 & 30.81 & 25.59 & 28.47 & \\
\hline Mean & 23.64 & 32.14 & 30.62 & 25.09 & & \\
\hline \multicolumn{7}{|c|}{ Leave dry weight $\left(\right.$ g plant $\left.^{-1}\right)$} \\
\hline Control & 12.90 & 15.20 & 14.40 & 13.32 & 13.96 & \multirow{5}{*}{$\begin{array}{c}\mathrm{T}=0.77 \\
\mathrm{Bi}=0.54 \\
\mathrm{~T} \times \mathrm{Bi}=0.91\end{array}$} \\
\hline Ammonium nitrate & 13.60 & 17.60 & 16.79 & 15.99 & 15.99 & \\
\hline Calcium nitrate & 13.30 & 14.95 & 14.43 & 14.01 & 14.17 & \\
\hline Ammonium sulfate & 13.45 & 16.51 & 15.79 & 15.00 & 15.18 & \\
\hline Mean & 13.31 & 16.07 & 15.33 & 14.58 & & \\
\hline
\end{tabular}

$\mathrm{K}-\mathrm{Hu}=\mathrm{K}-$ Humate, $\mathrm{K}-\mathrm{Cit}=\mathrm{K}-\mathrm{Citrate}$

Table (6): Leaf nutrient contents of sweet pepper as affected by different $\mathrm{N}$ sources and biostimulant applications.

\begin{tabular}{|c|c|c|c|c|c|c|}
\hline \multirow{2}{*}{ Treatments $(\mathbf{T})$} & \multicolumn{4}{|c|}{ Biostimulants (Bi) } & \multirow{2}{*}{ Mean } & \multirow{2}{*}{$\begin{array}{l}\text { L.S.D. } \\
\text { at } 5 \%\end{array}$} \\
\hline & $\mathbf{0}$ & K-Hu & K-Cit & Yeast & & \\
\hline \multicolumn{7}{|c|}{ Nitrogen \% } \\
\hline Control & 2.20 & 2.70 & 2.60 & 2.40 & 2.48 & \multirow{5}{*}{$\begin{array}{c}\mathrm{T}=0.31 \\
\mathrm{Bi}=0.22 \\
\mathrm{~T} \times \mathrm{Bi}=0.40\end{array}$} \\
\hline Ammonium nitrate & 3.60 & 4.90 & 4.30 & 4.00 & 4.20 & \\
\hline Calcium nitrate & 3.00 & 3.50 & 3.20 & 3.00 & 3.18 & \\
\hline Ammonium sulfate & 3.20 & 4.20 & 4.00 & 3.70 & 3.72 & \\
\hline Mean & 3.03 & 3.83 & 3.38 & 3.25 & & \\
\hline \multicolumn{7}{|c|}{ Phosphors \% } \\
\hline Control & 0.24 & 0.27 & 0.25 & 0.19 & 0.24 & \multirow{5}{*}{$\begin{array}{c}\mathrm{T}=0.02 \\
\mathrm{Bi}=0.03 \\
\mathrm{~T} \times \mathrm{Bi}=0.07\end{array}$} \\
\hline Ammonium nitrate & 0.30 & 0.45 & 0.37 & 0.31 & 0.36 & \\
\hline Calcium nitrate & 0.20 & 0.35 & 0.30 & 0.28 & 2.28 & \\
\hline Ammonium sulfate & 0.25 & 0.40 & 0.33 & 0.30 & 0.32 & \\
\hline Mean & 0.25 & 0.37 & 0.31 & 0.27 & & \\
\hline \multicolumn{7}{|c|}{ Potassium \% } \\
\hline Control & 1.40 & 2.00 & 1.80 & 1.60 & 1.70 & \multirow{5}{*}{$\begin{array}{c}\mathrm{T}=0.20 \\
\mathrm{Bi}=0.17 \\
\mathrm{~T} \times \mathrm{Bi}=0.40\end{array}$} \\
\hline Ammonium nitrate & 1.90 & 2.90 & 2.60 & 2.30 & 2.42 & \\
\hline Calcium nitrate & 1.50 & 2.50 & 2.00 & 1.90 & 1.98 & \\
\hline Ammonium sulfate & 1.80 & 2.70 & 2.20 & 2.00 & 2.18 & \\
\hline Mean & 1.65 & 2.53 & 2.15 & 1.69 & & \\
\hline
\end{tabular}

$\mathrm{K}-\mathrm{Hu}=\mathrm{K}$-Humate, $\mathrm{K}-\mathrm{Cit}=\mathrm{K}-\mathrm{Citrate}$

Fayoum J. Agric. Res. \& Dev., Vol.25, No.1, January, 2011 
The data revealed that maximum values of $\mathrm{N}, \mathrm{P}$ and $\mathrm{K}$ contents of pepper were obtained by $0.5 \mathrm{~g} \mathrm{~L}^{-1}$ of potassium humate and potassium citrate. These results are agreement with those obtained by Shakivora $\boldsymbol{e t}$ al. (2003) who found that the $\mathrm{N}$ content, proteins and nitrate reductase activity were increased in Phaseolus vulgaris by application of potassium humat at $0.1 \%$, potassium citrate applied at $0.5 \mathrm{~g} \mathrm{~L}^{-1}$ increased the uptake of $\mathrm{N}, \mathrm{P}$ and $\mathrm{K}$ in wheat grains over the control. In addition, soil application of potassium humate significantly increased $\mathrm{N}$, $\mathrm{P}$ and $\mathrm{K}$ contents in pepper at $0.5 \mathrm{~g} \mathrm{~L}^{-1}$ relative to their untreated controls. Also, potassium humate significantly increased $\mathrm{N}, \mathrm{P}$ and $\mathrm{K}$ contents in leaves and yield of Berry (Soltani et al., 2007).

\section{d. Fruit nutrient contents:}

As shown from data presented in Table (7) that N-sources had a positive effect on the mineral contents of sweet pepper fruits. Furthermore, biostimulants, either with potassium humate or citrate, significantly increased fruit mineral content as compared with control plants. However, there was insignificant difference between both of the two tested biostimulators on fruit mineral content. Nitrate form supplied either as ammonium nitrate or calcium nitrate significantly increased nitrate content over ammonium sulfate. This result is in accordance with that of Wang et al. (2009) who mentioned that nitrate accumulation in spinach shoots was dramatically increased with the increase of $\mathrm{NO}_{3}-\mathrm{N}$ in the nutrient solution. Also, concentration of nitrate in plant tissues was found to be dependent on the concentration of $\mathrm{N}$ present in the nutrient solution Kotsirasa et al. (2002). On the other hand, Saleh et al. (2006) noted that humic acid significantly decreased nitrogen nitrate content and improved fruit quality of treated vines.

Table (7): Fruit nutrient contents in sweet pepper as affected by applied different $\mathrm{N}$-sources and biostimulant applications.

\begin{tabular}{|c|c|c|c|c|c|c|}
\hline \multirow{2}{*}{ Treatments $(\mathbf{T})$} & \multicolumn{4}{|c|}{ Biostimulants (Bi) } & \multirow{2}{*}{ Mean } & \multirow{2}{*}{$\begin{array}{l}\text { L.S.D. } \\
\text { at } 5 \%\end{array}$} \\
\hline & $\mathbf{0}$ & K-Hu & K-Cit & Yeast & & \\
\hline \multicolumn{7}{|c|}{ Nitrate content $\left(\mathrm{mg} \mathrm{kg}^{-1}\right)$} \\
\hline Control & 44.0 & 50.0 & 47.0 & 45.0 & 46.50 & \multirow{5}{*}{$\begin{array}{c}\mathrm{T}=3.21 \\
\mathrm{Bi}=2.38 \\
\mathrm{~T} \times \mathrm{Bi}=2.50\end{array}$} \\
\hline Ammonium nitrate & 72.1 & 80.6 & 78.1 & 75.7 & 76.63 & \\
\hline Calcium nitrate & 64.5 & 74.1 & 71.1 & 70.2 & 69.97 & \\
\hline Ammonium sulfate & 69.8 & 76.2 & 74.2 & 72.7 & 73.23 & \\
\hline Mean & 62.60 & 70.22 & 67.61 & 65.90 & & \\
\hline \multicolumn{7}{|c|}{ Ca content $\left(\mathrm{mg} \mathrm{kg}^{-1}\right)$} \\
\hline Control & 240 & 281 & 264 & 257 & 260.5 & \multirow{5}{*}{$\begin{array}{c}\mathrm{T}=3.10 \\
\mathrm{Bi}=0.03 \\
\mathrm{~T} \times \mathrm{Bi}=12.0\end{array}$} \\
\hline Ammonium nitrate & 301 & 390 & 372 & 345 & 332.0 & \\
\hline Calcium nitrate & 273 & 342 & 321 & 302 & 334.5 & \\
\hline Ammonium sulfate & 287 & 361 & 345 & 320 & 328.5 & \\
\hline Mean & 275.3 & 343.5 & 325.5 & 328.5 & & \\
\hline \multicolumn{7}{|c|}{$K$ content $\left(\mathrm{mg} \mathrm{kg}^{-1}\right)$} \\
\hline Control & 320 & 300 & 280 & 260 & 290.0 & \multirow{5}{*}{$\begin{array}{c}\mathrm{T}=44.20 \\
\mathrm{Bi}=32.60 \\
\mathrm{~T} \times \mathrm{Bi}=35.0\end{array}$} \\
\hline Ammonium nitrate & 361 & 571 & 477 & 411 & 455.0 & \\
\hline Calcium nitrate & 300 & 399 & 372 & 350 & 355.3 & \\
\hline Ammonium sulfate & 321 & 449 & 432 & 401 & 400.8 & \\
\hline Mean & 325.5 & 429.8 & 390.3 & 353.5 & & \\
\hline
\end{tabular}

$\mathrm{K}-\mathrm{Hu}=\mathrm{K}$-Humate, K-Cit=K-Citrate

Fayoum J. Agric. Res. \& Dev., Vol.25, No.1, January, 2011 
Concerning to potassium and calcium content, it was noticed that nitrate form supplied either as ammonium nitrate or calcium nitrate significantly increased both elements as compared with other $\mathrm{N}$ forms. Both nitrate and ammonium can be taken up and metabolized by plants. Since, increasing the level of $\mathrm{NO}_{3}$ in the growing media stimulates organic anion synthesis and hence, cation accumulation. However, $\mathrm{N}$ forms preferential for crop growth much depends on plant species and other environmental factors. Results obtained in this work are in agreement with those of Kotsirasa et al (2002) who stated that the concentration of $\mathrm{K}, \mathrm{Ca}, \mathrm{Mg}$ and $\mathrm{NO}_{3}$ in all regions of cucumber fruit was higher when $\mathrm{NO}_{3}$ constituted $75 \%$ or more of the total $\mathrm{N}$ in the nutrient medium, but was reduced by increasing concentrations of $\mathrm{NH}_{4}$. Also, other researches reported that total uptake of $\mathrm{Ca}, \mathrm{Mg}$, and $\mathrm{K}$ decreased with increasing $\mathrm{NH}_{4}-\mathrm{N}$ proportion in the nutrient solution which suggests that $\mathrm{NH}_{4}-\mathrm{N}$ was competing with these cations in pepper fruits. Chance $\boldsymbol{e t}$ al. (1999) reported that applying $\mathrm{N}$ as ammonium nitrate significantly increased $\mathrm{Ca}$ content of spinach leaves as compared with ammonium sulfate and urea. In respect to biostimulants, it was found that $\mathrm{K}$ - humate have an enhancing effect on the absorption.

\section{e. Fruit quality parameters:}

Organoleptic properties expressed as (soluble solid) TSS and acidity in sweet pepper fruits Table (8) were significantly affected by both studied factors. Pepper plants received ammonium nitrate combined with potassium humate soil application under drip irrigation system had fruits with best organoleptic indicators, i.e., TSS and acidity. Results of Tabatabaei et al. (2007) indicted that TSS of strawberry fruits was increased with increasing $\mathrm{NH}_{4}$ ratio in the nutrient solution. Moreover, the fertilizer containing humic acid increased apple fruit weight, yield and soluble solid content (Li et al., 1999).

The vegetative growth and yield were harmony with the results of nutritional value indicators of fruits, where the effects of $\mathrm{N}$-sources and biostimulation treatments on sweet pepper plants were significantly interacted and enhanced all nutritional value indicators. Also, sweet pepper plants received $\mathrm{N}$ in the form of ammonium nitrate combined with potassium humate recorded the best nutritional value indicators, i.e., total carbohydrate contents, anthocyanin, ascorbic acid, total polyphenols, than the other treatments. This significant increase may be attributed to the favorable effect of this treatment on fruit weight (Table 4). In case of anthocyanin content, it was clear that the effect of applied $\mathrm{N}$-sources could be categorized in an ascending order of ammonium nitrate $>$ ammonium sulfate $>\mathrm{Ca}$ nitrate.

Nitrogen is considered a master element in plant nutrition and it plays an important role in all physiological growth processes of plant as stimulation of plant growth, yield and chemical constituents in different plants. However, considerable differences existed in the response of various species to different $\mathrm{N}$-sources. In addition to, organic and/or inorganic fertilizers exert beneficial effects on nutritional value of snap bean (El-Basyouny, 1995) and on soybean (Ahmed et al., 2002). Thus, the increase in carbohydrate content may be due to the activation of photosynthetic machinery as a result of stimulating effect of different $\mathrm{N}$ forms on photosynthetic process as $\mathrm{N}$ is a constituent of chlorophyll molecules.

Fayoum J. Agric. Res. \& Dev., Vol.25, No.1, January, 2011 
Table (8): Fruits quality parameters of sweet pepper as affected by different $\mathrm{N}$-sources and biostimulant applications.

\begin{tabular}{|c|c|c|c|c|c|c|}
\hline \multirow{2}{*}{ Treatments $(\mathbf{T})$} & \multicolumn{4}{|c|}{ Biostimulants (Bi) } & \multirow{2}{*}{ Mean } & \multirow{2}{*}{$\begin{array}{l}\text { L.S.D. } \\
\text { at } 5 \%\end{array}$} \\
\hline & $\mathbf{0}$ & K-Hu & K-Cit & Yeast & & \\
\hline \multicolumn{7}{|c|}{ T.S.S of fruits (g) } \\
\hline Control & 179 & 220 & 192 & 185 & 194.0 & \multirow{5}{*}{$\begin{array}{c}\mathrm{T}=33.10 \\
\mathrm{Bi}=27.16 \\
\mathrm{~T} \times \mathrm{Bi}=41.0\end{array}$} \\
\hline Ammonium nitrate & 277 & 590 & 507 & 495 & 467.3 & \\
\hline Calcium nitrate & 255 & 471 & 401 & 381 & 377.0 & \\
\hline Ammonium sulfate & 260 & 510 & 500 & 480 & 379.0 & \\
\hline Mean & 242.8 & 447.9 & 400.0 & 385.3 & & \\
\hline \multicolumn{7}{|c|}{ Acidity \% } \\
\hline Control & 3.82 & 4.21 & 4.00 & 3.97 & 4.00 & \multirow{5}{*}{$\begin{array}{c}\mathrm{T}=0.28 \\
\mathrm{Bi}=0.35 \\
\mathrm{~T} \times \mathrm{Bi}=0.43\end{array}$} \\
\hline Ammonium nitrate & 4.81 & 6.39 & 5.58 & 5.21 & 5.49 & \\
\hline Calcium nitrate & 4.31 & 5.20 & 4.82 & 4.37 & 4.68 & \\
\hline Ammonium sulfate & 3.62 & 5.66 & 5.07 & 4.97 & 4.83 & \\
\hline Mean & 4.14 & 5.37 & 4.87 & 4.63 & & \\
\hline \multicolumn{7}{|c|}{ Ascorbic acid (mg/100g FW) } \\
\hline Control & 105.6 & 118.5 & 109.2 & 100.7 & 108.5 & \multirow{5}{*}{$\begin{array}{c}\mathrm{T}=10.30 \\
\mathrm{Bi}=5.40 \\
\mathrm{~T} \times \mathrm{Bi}=5.20\end{array}$} \\
\hline Ammonium nitrate & 118.7 & 145.6 & 140.7 & 132.5 & 134.4 & \\
\hline Calcium nitrate & 110.9 & 130.0 & 125.5 & 123.8 & 122.6 & \\
\hline Ammonium sulfate & 114.5 & 134.1 & 132.1 & 126.2 & 126.7 & \\
\hline Mean & 112.4 & 132.1 & 126.9 & 120.8 & & \\
\hline \multicolumn{7}{|c|}{ Total carbohydrate \% } \\
\hline Control & 16.8 & 20.5 & 19.0 & 18.9 & 18.8 & \multirow{5}{*}{$\begin{array}{c}\mathrm{T}=1.20 \\
\mathrm{Bi}=0.90 \\
\mathrm{~T} \times \mathrm{Bi}=2.10\end{array}$} \\
\hline Ammonium nitrate & 22.2 & 26.0 & 24.6 & 22.7 & 23.9 & \\
\hline Calcium nitrate & 20.0 & 22.9 & 20.6 & 19.3 & 20.7 & \\
\hline Ammonium sulfate & 21.1 & 24.4 & 22.9 & 20.9 & 22.3 & \\
\hline Mean & 20.0 & 23.5 & 21.8 & 20.5 & & \\
\hline \multicolumn{7}{|c|}{ Total polyphenol \% } \\
\hline Control & 0.56 & 0.68 & 0.68 & 0.63 & 0.66 & \multirow{5}{*}{$\begin{array}{c}\mathrm{T}=0.02 \\
\mathrm{Bi}=0.04 \\
\mathrm{~T} \times \mathrm{Bi}=0.05\end{array}$} \\
\hline Ammonium nitrate & 0.64 & 0.97 & 0.89 & 0.87 & 0.84 & \\
\hline Calcium nitrate & 0.60 & 0.85 & 0.83 & 0.80 & 0.77 & \\
\hline Ammonium sulfate & 0.62 & 0.87 & 0.85 & 0.83 & 0.79 & \\
\hline Mean & 0.61 & 0.84 & 0.81 & 0.78 & & \\
\hline \multicolumn{7}{|c|}{ Anthocyanin (mg/100g DW) } \\
\hline Control & 42.0 & 75.2 & 72.7 & 70.1 & 65.0 & \multirow{5}{*}{$\begin{array}{c}\mathrm{T}=0.40 \\
\mathrm{Bi}=1.00 \\
\mathrm{~T} \times \mathrm{Bi}=2.90\end{array}$} \\
\hline Ammonium nitrate & 55.6 & 87.1 & 84.9 & 80.9 & 77.1 & \\
\hline Calcium nitrate & 50.9 & 84.0 & 80.3 & 78.7 & 73.5 & \\
\hline Ammonium sulfate & 53.7 & 80.1 & 78.2 & 76.7 & 72.1 & \\
\hline Mean & 50.6 & 81.6 & 79.0 & 76.6 & & \\
\hline
\end{tabular}

$\mathrm{K}-\mathrm{Hu}=\mathrm{K}-\mathrm{Humate}, \mathrm{K}-\mathrm{Cit}=\mathrm{K}-\mathrm{Citrate}$

Moreover, the increase in phenolic content may be attributed to the increase in carbohydrate content. Since, phenolic compounds occur in pepper in connection with sugar. These results are in agreement with those outlined by Matersk $\boldsymbol{e t}$ al. (2003) who mentioned that $\mathrm{N}$ forms markedly increased soluble sugar content (total, reducing and non reducing) and ascorbic acid. Moreover, the highest ascorbic acid concentration of pepper was recorded with ammonium nitrate followed by ammonium sulfate and calcium nitrate. Regarding the biostimulants, the humic substances can affect plant physiology and stimulate growth due to their hormone like activity, where humic substances have cytokinin and auxin.

Fayoum J. Agric. Res. \& Dev., Vol.25, No.1, January, 2011 
Chen and Avaid (1990) and Zaghloul et al. (2009) stated that application of potassium humate increased soluble sugar content of Thuya orientalis L. shoots compared to control. Moreover, application of humic acid significantly increased ascorbic acid and endogenous antioxidants of Kentucky bluegrass (Zhang and Schmidt, 1999). The most interesting result in this study is the increase of ascorbic acid, total polyphenols and anthocyanin in pepper fruits resulted from the application of two studied factors. Since, these compounds play an important role in increase fruit quality as they considered important antioxidants for human nutrition (Guil-Guerrero, and Martinez-Guirado, 2006). These antioxidants perform their function by counteracting the oxidizing effect on lipids by scavenging highly reactive oxygen free radicals.

\section{CONCLUSION:}

From the aforementioned results, it can be concluded that, the application of biostimulants (potassium humate, potassium citrate and yeast) as soil application through drip irrigation system under saline calcareous soil increased sweet pepper yield. The growth and yield parameters of pepper plants via the enhancement of the biosynthesis of photosynthetic pigments as well as improved as a result of the nutritional status of pepper plants grown on a newly reclaimed soil and also to find whether biostimulants (potassium humate, potassium citrate and yeast) had a beneficial effect on early and total yields as well as fruit quality of sweet pepper with a relatively higher ability for increasing available micronutrients in the soil.

\section{REFERENCE:}

Ahmed, K.A.; M.M. Badran and S.H. Ashmawy, 2002. Response of soybean to chemical and biofertilization. Egypt. J. of Appl. Sci., 17: 207-218.

Ahmed, O.H.; H, Aminuddin; M.H.A. Husni; A.R. Anuar and A.M. Nik Muhamad, 2008. Enhancing the urea-N use efficiency in Maize (Zea mays) cultivation on acid soils amended with zeolite and TSP. The Scientific World J., 8: 394-399.

Ahmed, O.H.; H. Aminuddin and M.H.A. Husni, 2006. Effects of urea, humic acid and phosphate interactions in fertilizer microsites on ammonia volatilization and soil ammonium and nitrate contents. Int. J. Agric. Res., 1: 2531.

Amin A.A. and Rashad El-Sh, Fatma M., 2008. Changes in morphological, physiological and reproductive characters of wheat plants as affected by foliar application with salicylic acid and ascorbic acid. Aust. J. Basic Appl. Sci., 2:252-61.

Antoun, G.G. and Y.B. Besada, 1990. Nitrogen transformation during mineralization of some organic materials in clay soil. Agric. Res. Review, 68(2):373

AOAC, 1990. Official Methods of Analysis $15^{\text {th }}$ Ed, Association of Official Analytical Chemists, Washington DC.

Arfan, M.; R. Athar and M. Ashraf, 2007. Does exogenous application of salicylic acid through the rooting medium modulate growth and photosynthetic capacity in two differently adapted spring wheat cultivars under salt stress. J. Plant Physiol., 164: 685-694

Fayoum J. Agric. Res. \& Dev., Vol.25, No.1, January, 2011 
Baker, A.S.; R. Ben Yahuda and U. Kafkafi, 1980. Effect of rate, source and distribution method of nitrogen fertilizer on seed potato production. J. Agric. Sci., 94: 745-747.

Baraldi, R.; F.F.F., Malavasi; S. Predieri and M. Castagneto, 1991. Effect of potassium humate on apple cv. "Golden Delicious" cultured in vitro. Plant Cell, Tissue and Organ Culture, 24: 187-191.

Beames, G.H., 1986. Use of humic substances as agricultural plant biostimulants. Eighth Rocky Mountain Regional Meeting, American Chemical Society, 17 pp.

Black, C.A.; D.D. Evans; J.L. White; L.E. Ensiminger and F.E. Clark, 1982. Methods of Soil Analysis. Amer. Soc. Agron Inc., Ser. 9 in Agron. Madison, Wisconsin, USA

Bryan, H.H., 1976. Response of tomatoes to seed and seedling applications of humates and alphaketo acids. Proceedings of the Florida State Horticultural Society, 89: 87-90.

Chance, W.O.; Z.C. Somda and H.A. Mills, 1999. Effect of nitrogen form during the flowering period on zucchini squash growth and nutrient element uptake. J. Plant Nutrition, 22: 597-607

Chen, Y. and T. Aviad, 1990. Effects of humic substances on plant growth. In: Humic Substances in Soil and Crop Science: Selected Readings. MacCanthy, P.; C.E. Clapp; R.L. Macolm and P.R. Bloom (Eds.). Soil Sci. of Am., Madison, Wisconsin, USA.

Cox, R.S. and L.A. Nelson, 1984. Compatibility evaluation of various foliar spray combinations on pepper. Proceedings of the Florida State Horticultural Society, 97:187-190.

David, P.P., P.V. Nelson and D.C. Sanders, 1994. A humic acid improves growth of tomato seedling in solution culture. Journal of plant nutrition, 17: 173-184.

Ebeed, S. and M.M.M., Abd El-Migeed, 2005. Effect of spraying sucrose and some nutrient elements on Fagri Kalan mango trees. J. Appl. Sci. Res., 1: 341346.

El-Basyouny, M.S.S., 1995. The response of snap bean to some nutritional levels of macro and micro- elements. M. Sc. Thesis, Fac. of Agric., Al-Azhar University.

Ghoname, A.A.; Mona.G. Dawood, G.S. Riad and W.A. El-Tohamy, 2009. Effect of Nitrogen Forms and Biostimulants Foliar Application on the Growth, Yield and Chemical Composition of Hot Pepper Grown under Sandy Soil Conditions Research Journal of Agric. and Biological Sci., 5(5): 840-852.

Gomez, K.A. and A.A. Gomez, 1984. Statistical procedures for agriculture research. Second Ed. Wiley Inter. Science Publ., John Wiley \& Sons, New York

Guertal, E.A., 2000. Pre-plant slow-release nitrogen fertilizers produce similar bell pepper yields as split applications of soluble fertilizer. Agron. J., 92: 388393.

Guil-Guerrero, J.L. and C. Martinez-Guirado, 2006. Nutrient composition and antioxidant activity of 10 pepper (Capsicum annuum) varieties. European Food Res. and Technology, 224: 1-9.

Fayoum J. Agric. Res. \& Dev., Vol.25, No.1, January, 2011 
Hochmuth, G.J.; K.D. Shuler; R.L. Mitchell and P.R. Gilreath, 1987. Nitrogen crop nutrient requirement demonstrations for mulched pepper in Florida. Proceedings of the Florida State Horticultural Society, 100: 205-209.

Houdusse, F.; M. Garnica and J.M. García-Mina. 2007. Nitrogen fertilizer source effects on the growth and mineral nutrition of pepper (Capsicum annuum L.) and wheat (Triticum sativum L.). J. Sci. Food and Agric., 87(11): 2099-2105

Kotsirasa, A.; C.M. Olympiosa; J. Drosopoulosb and H.C. Passam. 2002. Effects of nitrogen form and concentration on the distribution of ions within cucumber fruits. Scientia Horticulturae, 95: 175- 183.

Jackson, M.L., 1973. Soil Chemical Analysis. Prentice-Hall of Indian private, Limited, New Delhi, India.

Li, N.; X. Wang and B.L. Lu, 1999. Study of the effect of apple liquid fertilizers on the growth and fruit development of starkrimson apple variety (in Chinese). China Fruits, 4:20-21, (c.f. Hort. Abs. 705: 3628).

Lindsay, W.l. and W.A. Norvell, 1978. Development of DTPA soil test for Zn, Mn and Cu. Soil Sci. Soc. Am. J., 24:421- 427.

Marchner, H., 1995. Mineral nutrition in higher plants. Acad. Inc., London, UK., pp: 887.

Matersk, M.; S. Piacente; A. Stochmal; C. Pizza; W. Oleszek and I. Perucka, 2003. Isolation and structure elusidation of flavonoid and phenolic acid glycosides from pericarp of hot pepper fruit Capsicum annuum L. Phytochemistry, 63: 893-89.

McNeal, B.L.; C.D. Stanley; W.D. Graham; P.R. Gilreath; D. Downey and J.F. Creighton, 1995. Nutrient-loss trends for vegetable and citrus fields in west-central Florida: I. Nitrate. Journal of Environmental Quality, 24: 95-100.

Nielsen, S.S., 1998. Food Analysis. Aspen Publishers, Inc. Gaithersburg, MD. USA., pp: 630.

Piper, C.S. 1950. Soil and Plant Analysis. Inter. Sci. Publisher Inc., New York, USA.

Pizzeghello, D.; G. Nicolini and S. Nardi, 2002. Hormone-like activities of humic substances in different forest ecosystems. New Phytologist, 155: 393-402.

Richards, L.A., 1954. Diagnosis and Improvement of saline and alkali soils. Agric. Handbook No. 60. USD Agric., Washington, USA.

Saleh, M.M.S.; S. El-Ashry and A.M. Gomaa, 2006. Performance of Thompson seedless grapevine as influenced by organic fertilizer, humic acid and biofertilizers under sandy soil conditions. Res. J. Agric. and Biological Sci., 2: 467-741.

Sarro, M.J.; L. Gonzáles and J.M. Peñalosa, 1995. Response of pepper plants to different periods of nitrate and ammonium fertilization. Acta Horticulturae, 412: 439-446.

Schuphan, W., 1974. Nutritional value of crops as influenced by organic and inorganic fertilizer treatments. Qualitas Plantarum, 23(4): 333-50.

Shakirova, F.M.; A.R. Sakhabutdinova; M.V. Bezrukova; R.A. Fathkutdinov and D.R. Fatkhutdinova, 2003. Changes in the hormonal status of wheat seedlings induced by salicylic acid and salinity. Plant Sci., 164: 317.

Fayoum J. Agric. Res. \& Dev., Vol.25, No.1, January, 2011 
Smith, F.; M.A. Gilles; J.K. Hamilton and P.A. Godees, 1956. Colorimetric method for determination of sugar related substances. Analytical Chemistry, 28: 350 .

Soltani, F.; A. Kashi and M. Babalar, 2007. Effect of nitrogen form on yield, fruit number and leaf nutrient content of two greenhouse cucumber cultivars in soilless culture. Acta Horticulturae, 731: 273-276.

Tabatabaei, S.J.; M. Yusefi and J. Hajiloo, 2007. Effects of shading and NO : $\mathrm{NH}$ ratio on the yield,quality and $\mathrm{N}$ metabolism in strawberry. Scientia Horticulturae, 116: 264-272.

Tan, K.H., 2005. Determination of Soil Water. In: Soil Sampling, Preparation and Analysis, $2^{\text {nd }}$ Ed., CRC Press, Taylor and Francis Group, USA.

Tan, K.H.; D.S. Himmelsbach and J.C. Lobartini, 1992. The significance of solid-state 13C NMR spectroscopy of whole soil in the characterization of humic matter. Commun. Soil Sci. Plant Anal., 23: 1513-1532.

Tibor, F. and F.J. Francis, 1967. Quantitative methods for anthocyanins. Journal of Food Science, 33: 1-5.

Wang, J.; Y. Zhou1; C. Dong; Q. Shen and R. Putheti, 2009. Effects of $\mathrm{NH}_{4} \mathrm{~N} /$ $\mathrm{NO}_{3}-\mathrm{N}$ ratios on growth, nitrate uptake and organic acid levels of spinach (Spinacia oleracea L.). African J.1 of Biotechnology, 8: 3597-3602.

Wettasinghe, M. and F. Shahidi, 1999. Evening primrose meal: a source of natural antioxidants and scavenger of hydrogen peroxide and oxygen derived free radicals. J. Agric. and Food Chemistry, 47: 1801-1812.

Wiesler, F., 1997. Agronomical and physiological aspects of ammonium and nitrate nutrition of plants. Zeitschrift für Pflanzenernährung und Bodenkunde 160: 227-238.

Xu, G., S. Wolf and U. Kafkafi, 2002. Ammonium on potassium interaction in sweet pepper. J. Plant Nutrition, 25: 719-734.

Zaghloul, S.M.; F.E.M., El-Quesni and A.A.M. Mazhar, 2009. Influence of potassium humate on growth and chemical constituents of Thuja orientalis $\mathrm{L}$ seedlings. Ozean J. Appl. Sci., 2: 73-78.

Zhang, X. and R.E. Schmidt, 1999. Antioxidant response to hormone-containing product in Kentucky blue grass subjected to drought. Crop Science, 39: 545551.

Fayoum J. Agric. Res. \& Dev., Vol.25, No.1, January, 2011 
تأثير إضافة مصادر مختلفة من النتروجين ويعض المحفزات الحيوية_العضوية على نباتات

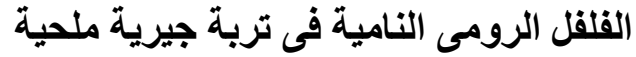

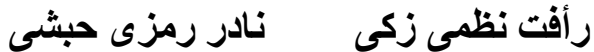

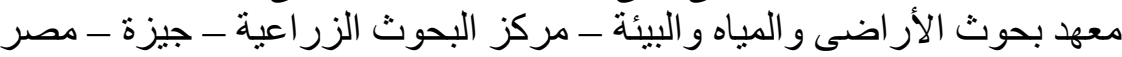

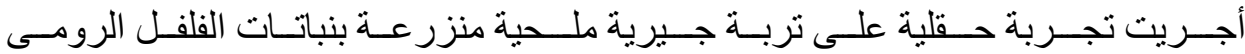

(Capsicum annuum L.)

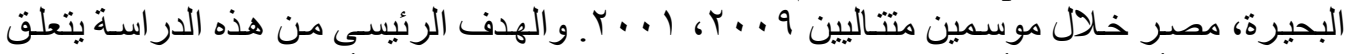

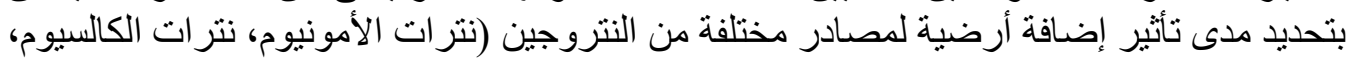

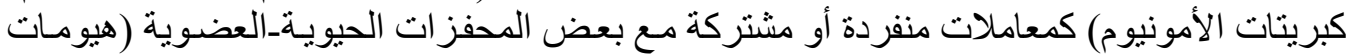

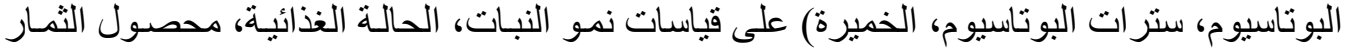

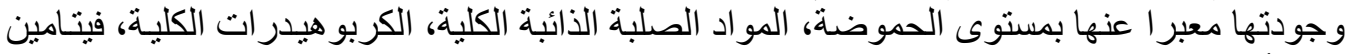

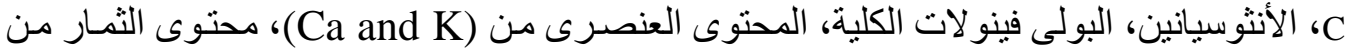

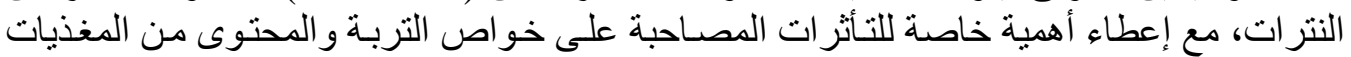

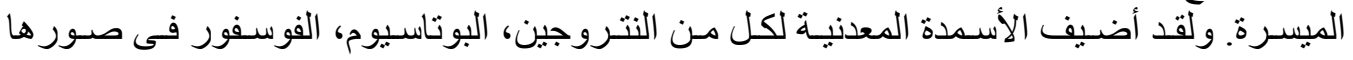

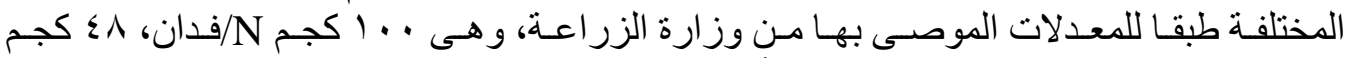

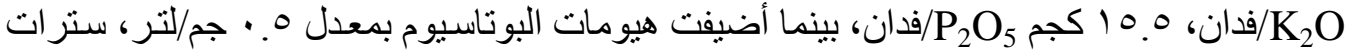

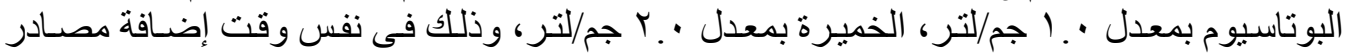

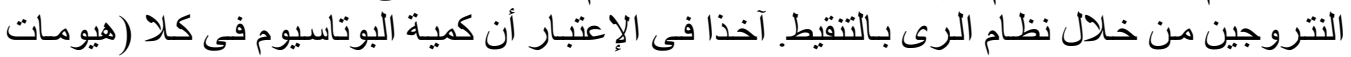

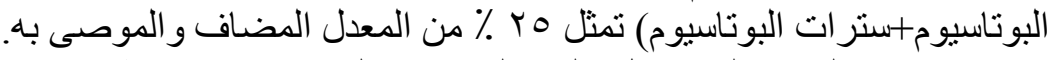

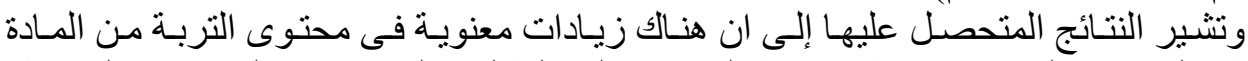

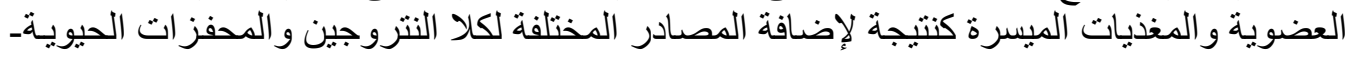

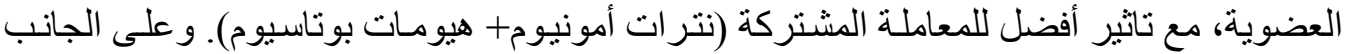

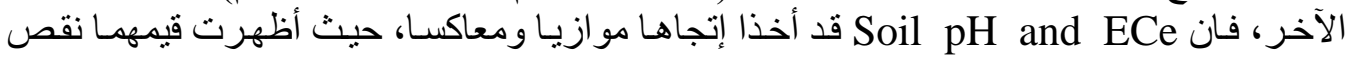
معنوى، مع ناثير أفضل للمعاملة المشتركة السابق ذكر ها.

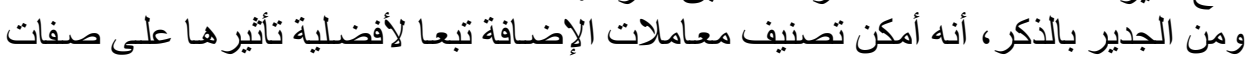

التربة تحت الدر اسة فى ترنبين تنازليين: Am-Ni > Am-Su > Ca-Ni and K-Hu > K-Ci

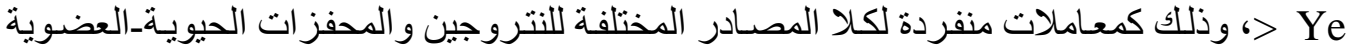

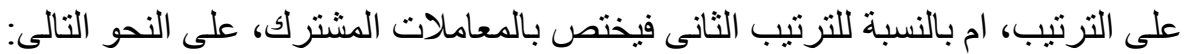
$(\mathrm{Am}-\mathrm{Ni}+\mathrm{K}-\mathrm{Hu})>(\mathrm{Am}-\mathrm{Ni}+\mathrm{K}-\mathrm{Ci})>(\mathrm{Am}-\mathrm{Ni}+\mathrm{Ye}),(\mathrm{Am}-\mathrm{Su}+\mathrm{K}-\mathrm{Hu})>(\mathrm{Am}-\mathrm{Su}+\mathrm{K}-\mathrm{Ci})>$ $(\mathrm{Am}-\mathrm{Su}+\mathrm{Ye})$ and $(\mathrm{Ca}-\mathrm{Ni}+\mathrm{K}-\mathrm{Hu})>(\mathrm{Ca}-\mathrm{Ni}+\mathrm{K}-\mathrm{Ci})>(\mathrm{Ca}-\mathrm{Ni}+\mathrm{Ye})$

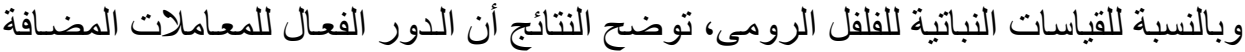

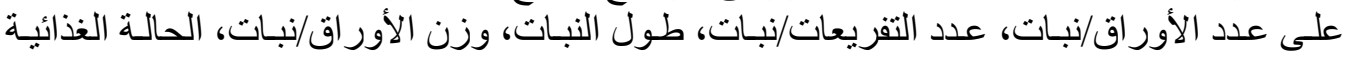

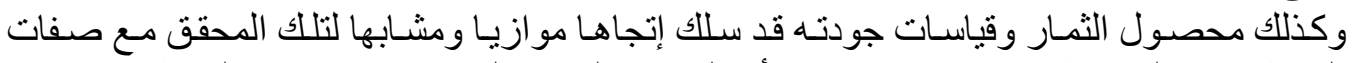

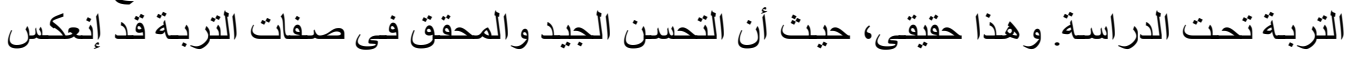

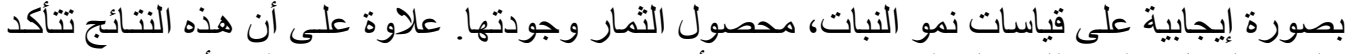

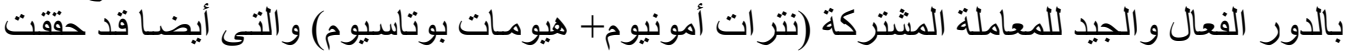

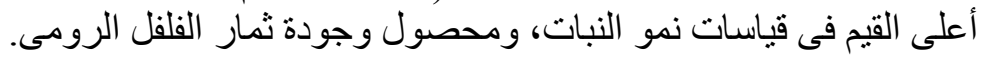

Fayoum J. Agric. Res. \& Dev., Vol.25, No.1, January, 2011 